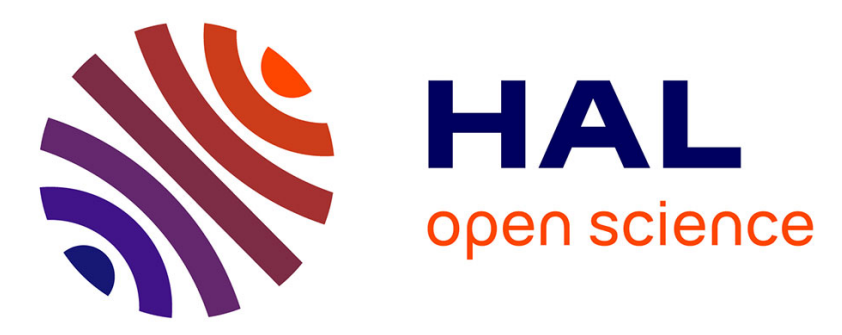

\title{
Neuropeptide FF-sensitive confinement of mu opioid receptor does not involve lipid rafts in SH-SY5Y cells.
}

Lionel Moulédous, Soren Merker, Jérémie Neasta, Benoit Roux, Jean-Marie Zajac, Catherine Mollereau

\section{- To cite this version:}

Lionel Moulédous, Soren Merker, Jérémie Neasta, Benoit Roux, Jean-Marie Zajac, et al.. Neuropeptide FF-sensitive confinement of mu opioid receptor does not involve lipid rafts in SH-SY5Y cells.. Biochemical and Biophysical Research Communications, 2008, 373 (1), pp.80-4. 10.1016/j.bbrc.2008.05.174 . hal-00316149

\section{HAL Id: hal-00316149 \\ https://hal.science/hal-00316149}

Submitted on 2 Sep 2008

HAL is a multi-disciplinary open access archive for the deposit and dissemination of scientific research documents, whether they are published or not. The documents may come from teaching and research institutions in France or abroad, or from public or private research centers.
L'archive ouverte pluridisciplinaire HAL, est destinée au dépôt et à la diffusion de documents scientifiques de niveau recherche, publiés ou non, émanant des établissements d'enseignement et de recherche français ou étrangers, des laboratoires publics ou privés. 


\section{Neuropeptide FF-sensitive confinement of mu opioid}

\section{receptor does not involve lipid rafts in SH-SY5Y cells}

Lionel Moulédous ${ }^{1 *}$, Soren Merker, Jérémie Neasta, Benoit Roux, Jean-Marie Zajac, and Catherine Mollereau.

1 Institut de Pharmacologie et de Biologie Structurale, CNRS / Université de Toulouse, UMR 5089, 205 route de Narbonne, 31077 Toulouse Cedex, France

Abbreviations: 1DMe, $\left[\mathrm{D}-T y r^{1},(\mathrm{NMe}) \mathrm{Phe}^{3}\right]$ neuropeptide FF; DRM, detergent resistant membrane; GFP, green fluorescent protein; $\mathrm{M} \beta \mathrm{CD}$, methyl- $\beta$-cyclodextrin; MOP, mu opioid; NPFF, neuropeptide FF; vrFRAP, fluorescence recovery after photobleaching at variable observation radius; YFP, yellow fluorescent protein.

* To whom correspondence should be addressed: IPBS; 205 rte de Narbonne, 31077, Toulouse, France. Phone: +33 5611759 22. Fax: +33 5611759 94. lionel.mouledous@ipbs.fr 


\begin{abstract}
$\mathrm{Mu}$ opioid (MOP) receptor activation can be functionally modulated by stimulation of Neuropeptide FF $2\left(\mathrm{NPFF}_{2}\right) \mathrm{G}$ protein-coupled receptors. Fluorescence recovery after photobleaching experiments have shown that activation of the $\mathrm{NPFF}_{2}$ receptor dramatically reduces the fraction of MOP receptors confined in microdomains of the plasma membrane of SH-SY5Y neuroblastoma cells. The aim of the present work was to assess if the direct observation of receptor compartmentation by fluorescence techniques in living cells could be related to indirect estimation of receptor partitioning in lipid rafts after biochemical fractionation of the cell. Our results show that MOP receptor distribution in lipid rafts is highly dependent upon the method of purification, questioning the interpretation of previous data regarding MOP receptor compartmentation. Moreover, the NPFF analogue 1 DMe does not modify the distribution profile of MOP receptors, clearly demonstrating that membrane fractionation data do not correlate with direct measurement of receptor compartmentation in living cells.
\end{abstract}

Keywords: opioid, neuropeptide FF, lipid rafts, membrane fractionation, cholesterol. 


\section{Introduction}

Neuropeptide FF (NPFF), FLFQPQRFamide, belongs to a family of neuropeptides who, among other roles, modulate the opioid system [1-3]. Peptides issued from two precursors, pro-NPFF and pro$\mathrm{NPFF}_{\mathrm{B}}$, bind specifically to two $\mathrm{G}$ protein-coupled receptors, $\mathrm{NPFF}_{1}$ and $\mathrm{NPFF}_{2}$ [4]. Studies on isolated neurons have shown that the anti-opioid activity of NPFF could result from a cross-talk between NPFF and opioid systems within the same cell (for review see [5]). In order to study the mechanism of NPFF anti-opioid activity SH-SY5Y neuroblastoma cells that endogenously express opioid receptors were transfected with the human $\mathrm{NPFF}_{2}$ receptor. In this cellular model, NPFF analogs functionally antagonize the inhibition of N-type voltage gated calcium channels by $\mu$ and $\delta$ opioid ligands [6]. Moreover, fluorescence energy transfer studies revealed that $\mathrm{NPFF}_{2}$ and $\mu$ opioid (MOP) receptors could form heteromers [7]. Finally, fluorescence recovery after photobleaching at variable observation radius (vrFRAP) experiments were used to follow the lateral diffusion of YFP-tagged MOP receptors in the plasma membrane. These analyses showed that about 54\% of MOP receptors were compartmentalized under control conditions and that treatment with $1 \mathrm{DMe}\left(\left[\mathrm{D}^{-\mathrm{Tyr}^{1}}{ }^{1},(\mathrm{NMe}) \mathrm{Phe}^{3}\right]\right.$ neuropeptide $\left.\mathrm{FF}\right), \mathrm{a} \mathrm{NPFF}_{2}$ receptor agonist, increased the percentage of freely diffusing MOP receptors to about 80\% [7], indicating that activation of NPFF receptors could change the lateral mobility behavior of MOP receptors.

MOP receptor compartmentation could be due to lipid raft microdomains that are formed by clustering of cholesterol and sphingolipids, resulting in liquid-ordered lipid phases that could serve as signaling platforms $[8,9]$. Several $\mathrm{G}$ protein-coupled receptors $[10,11]$ including $\mu, \delta$ and $\kappa$ opioid receptors $[12-$ 19] have been proposed to be enriched in such domains, based on membrane fractionation and cholesterol depletion experiments. The fact that MOP receptor lateral diffusion was modified by $1 \mathrm{DMe}$ treatment in our cellular model gave us a unique opportunity to test the equivalence between direct measurement of receptor compartmentation by fluorescence techniques in living cells and indirect estimation of receptor distribution by biochemical fractionation of the membrane. Our results show that 
MOP receptor partitioning is highly dependent upon the method used to purify lipid rafts, questioning the interpretation of previous data obtained from membrane fractionation analyses. Moreover our data clearly demonstrate that membrane fractionation data do not correlate with direct measurement of receptor compartmentation in living cells.

\section{Materials and Methods}

Vector constructions. The YFP cDNA (generous gift from R. Tsien, UCSD) was transferred from a pBluescript II SK ${ }^{-}$YFP construct [7] to the 3 ' end of the human $\mathrm{NPFF}_{2}$ receptor cDNA also in pBluescript II $\mathrm{SK}^{-}$using NcoI and XbaI restriction sites. The construct was then inserted into the EcoRV-XbaI sites of the mammalian expression vector pEFIB3 bearing the blasticidin selection marker. The construct was verified by sequencing (Genome Express, Meylan, France).

Cell culture and transfection. The $\mathrm{NPFF}_{2}-\mathrm{YFP}$ cell line was obtained by transfecting SH-SY5Y neuroblastoma cells using FuGENE 6 (Roche Applied Science, Bale, Switzerland) according to manufacturer's instructions. Stable cell lines were obtained by subcloning and selection with $5 \mu \mathrm{g} / \mathrm{ml}$ blasticidin (Cayla, Toulouse, France). Cells expressing the C-terminal yellow fluorescent protein (YFP)tagged human MOP receptor together with untagged-NPFF 2 receptors [7] were grown in high glucose DMEM (Invitrogen, Carlsbad, CA) containing 10\% fetal calf serum, $50 \mu \mathrm{g} / \mathrm{ml}$ gentamicine (Invitrogen), $400 \mu \mathrm{g} / \mathrm{ml} \mathrm{G} 418$ and $2 \mu \mathrm{g} / \mathrm{ml}$ blasticidin in $5 \% \mathrm{CO}_{2}$ at $37^{\circ} \mathrm{C}$. Cells expressing the C-terminal YFPtagged human $\mathrm{NPFF}_{2}$ receptor were grown under the same conditions except that no G418 but $5 \mu \mathrm{g} / \mathrm{ml}$ of blasticidin were used for selection.

Measurement of intracellular cAMP. Intracellular cAMP was measured after incorporation of $\left[{ }^{3} \mathrm{H}\right]$ adenine and selective batch elution on acidic alumina columns as previously described [20].

Isolation lipid rafts using detergent. Cells were solubilized in $0.2 \%$ Triton X-100 (Sigma, St. Louis, MO) and the detergent resistant membranes were isolated by centrifugation on discontinuous sucrose gradients as previously described [20]. 
Detergent-free isolation of lipid rafts. The detergent-free procedure was adapted from [21] with minor modifications. Cells (from 2 confluent 150-mm dishes) were harvested in $2 \mathrm{ml}$ of ice-cold 500 $\mathrm{mM}$ sodium carbonate, $\mathrm{pH} 11$. The suspension was first homogenized 3 x $10 \mathrm{~s}$ using an Ultra-Turrax T25 (Janke \& Kunkel, IKA-Labortechnik, Staufen, Germany) then 3 x 20 s using a VibraCell sonicator (Bioblock Scientific, Illkirch, France). The homogenate was then mixed at the bottom of $12 \mathrm{ml}$ Polyallomer centrifuge tubes (Beckman, Fullerton, CA) with $2 \mathrm{ml}$ of $90 \%$ sucrose prepared in MBS (25 mM MES, 0,15 M NaCl) containing proteinase inhibitors (Complete Mini tablets, Roche). The resulting $45 \%$ sucrose layer was overlaid successively with $4 \mathrm{ml}$ of $35 \%$ sucrose and $4 \mathrm{ml}$ of $5 \%$ sucrose in MBS containing $250 \mathrm{mM}$ sodium carbonate, and centrifuged at $39,000 \mathrm{rpm}$ for $18 \mathrm{hr}$ at $4^{\circ} \mathrm{C}$ in a SW41 rotor in a Beckman Optima LE-80K Ultracentrifuge. Twelve 1-ml fractions were collected from the top down. Alkaline phosphatase activity was measured in $50 \mu 1$ of each fraction using Sigma FAST p-nitrophenyl phosphate tablet sets.

Western blot analysis. Samples were solubilized in SDS-PAGE sample buffer containing 5\% $\beta$ mercaptoethanol by boiling for $5 \mathrm{~min}$ at $100^{\circ} \mathrm{C}$. Proteins (an equal volume from each fraction) were subjected to SDS-PAGE on 10\% polyacrylamide gels followed by liquid transfer on PVDF membranes (Immobilon-P, Millipore, Bedford, MA). The following antibodies were used for immunoblotting: monoclonal anti-flotillin1 (Transduction Laboratories, Lexington, KY), polyclonal anti-GFP (Santa

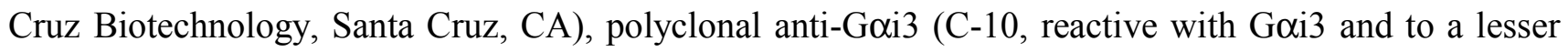

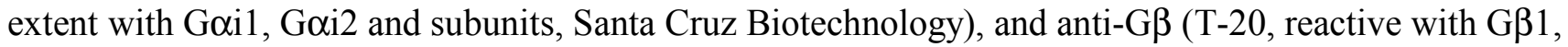

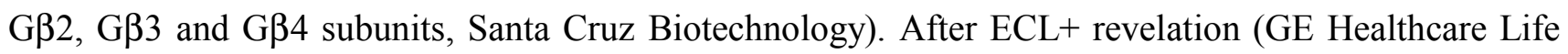
Sciences, Piscataway, NJ), chemiluminescence was detected using both a Typhoon 9410 imager (GE Healthcare Life Sciences), for quantification, and X-ray films. When required, blots were quantified using the ImageQuant TL software (GE Healthcare Life Sciences).

Data analysis. Experimental data fitting and statistical analysis were performed using Prism (GraphPad Software, San Diego, CA). Statistical significance between groups of data was assessed 
using Student's t test.

\section{Results and discussion}

Mu opioid receptors do not behave as canonical lipid raft proteins in SH-SY5Y cells

Isolation of detergent-resistant membranes (DRMs) is the most widely used method for studying the affinity of membrane proteins for lipid rafts [22]. Solubilization of SH-SY5Y cells expressing MOPYFP receptors in $0.2 \%$ Triton $\mathrm{X}-100$ followed by sucrose gradient centrifugation indeed produced detergent-resistant low density fractions containing two classical lipid raft markers: GPI-anchored alkaline phosphatase and palmitoylated flotillin-1 (figure 1, left panel, fractions 3 and 4). Both proteins are totally absent from heavy fractions. MOP-YFP behaved in an opposite way, being almost undetectable in DRMs (figure 1, left panel). Previous studies that have described the enrichment of MOP receptors in lipid raft fractions have used alternative detergent-free methods of isolation based on homogenization in $500 \mathrm{mM}$ sodium carbonate at $\mathrm{pH} 11[15,16,19]$. By using a similar protocol, the large majority of MOP-YFP are observed in low density fractions together with the raft markers alkaline phosphatase and flotillin (figure 1, right panel, fractions 4 and 5). After detergent-free extraction, some alkaline phosphatase and flotillin were also present in heavy fractions in contrast to MOP-YFP receptors (figure 1, right panel, fractions 9 to 12). Thus, even when it is found in lipid raft fractions, the MOPYFP receptor does not behave as do classical lipid raft markers. In the present study we used YFPtagged MOP receptors in order to compare with FRAP experiments that had been performed using this fusion protein. However a possible influence of YFP on the partitioning of MOP receptors can be ruled out as similar results were obtained using a receptor bearing only a small T7 tag at its N-terminus (data not shown). 
Another indirect way of assessing the importance of lipid raft localization for a GPCR is to study the consequences of cholesterol depletion by methyl- $\beta$-cyclodextrin $(\mathrm{M} \beta \mathrm{CD})$ on its signaling in living cells. One hour treatment with $5 \mathrm{mM}$ of $\mathrm{M} \beta \mathrm{CD}$ induced a partial redistribution of MOP-YFP receptors towards the heavy fractions of the sucrose gradient after detergent-free extraction (figure 2A). This redistribution was correlated with a statistically significant 5.4 fold increase of the $\mathrm{EC}_{50}$ of the MOP receptor agonist DAMGO for the inhibition of adenylyl cyclase $(\mathrm{p}<0.05,1.6$ vs $8.6 \mathrm{nM})$. This result indicates that the lipidic environment of the receptor plays a part in its activity [23]. However, the fact that MOP receptors are excluded from DRMs clearly shows that their "raftophilicity" [22] is rather low. This conclusion strengthens previous reports demonstrating that, contrary to GPI-anchored or palmitoylated proteins, integral membrane proteins are often excluded from DRMs despite being found in low density fractions after detergent-free extraction [24-26]. A possible explanation for this discrepancy could be that the physicochemical properties of the MOP receptor do not favor its association with lipid rafts fractions but that it is still loosely associated with this compartment by specific protein/lipid or protein/protein interactions that resist detergent-free extraction. The necessity for these specific interactions could also explain why lipid rafts association and cholesterol dependency of the MOP receptor is region-specific in the rat brain [16].

$\mathrm{NPFF}_{2}$ receptors are predominantly found outside lipid rafts in SH-SY5Y cells

A stable SH-SY5Y cell line was also constructed in order to study the distribution of the human $\mathrm{NPFF}_{2}$ receptor fused to YFP at its C-terminus. The correct expression of the construct was confirmed by confocal microscopy (data not shown) as well as by the fact that 1DMe was able to potently inhibit adenylyl cyclase in these cells (Figure 3B). As previously described [7], 2 forms of $\mathrm{NPFF}_{2}$ receptors at about 130 and $90 \mathrm{kDa}$ were detected by western-blot against GFP. Concerning the lower form, Triton X100 and detergent-free extraction methods gave similar results with no detectable $\mathrm{NPFF}_{2}$ receptors in lipid raft fractions (Figure 3A). However, the distribution of the band corresponding to the heavier form 
along the sucrose gradient showed some variability between repeated detergent-free extraction experiments ( 10 to $50 \%$ of this heavy form was found in buoyant fractions). Nevertheless, unlike MOPYFP receptors, cholesterol depletion by $5 \mathrm{mM} \mathrm{M} \beta \mathrm{CD}$ had no significant effect on $\mathrm{NPFF}_{2}$-YFP receptor signaling $\left(\mathrm{EC}_{50}\right.$ of $1 \mathrm{DMe}$ for the inhibition of adenylyl cyclase was $10 \mathrm{nM}$ in control cells and $7.2 \mathrm{nM}$ in depleted cells, figure 3B). We can thus conclude that, in SH-SY5Y cells, $\mathrm{NPFF}_{2}-\mathrm{YFP}$ receptor signaling is not confined in putative cholesterol-rich lipid raft microdomains.

MOP-containing lipid domains isolated by detergent-free extraction are not equivalent to confinement areas observed in living cells

We and others have demonstrated using FRAP technique that MOP receptors lateral diffusion at the surface of SH-SY5Y cells is confined in microdomains with radii ranging from 0.7 to $1 \mu \mathrm{m}[7,27]$. We have also shown that MOP receptor confinement was disrupted by 1DMe treatment [7]. If the MOPenriched membrane domains obtained after detergent-free extraction (figure 1, right panel) were equivalent to the domains responsible for receptor compartmentation observed by fluorescence techniques in living cells then $1 \mathrm{DMe}$ treatment should also disrupt receptor distribution along the sucrose gradient. Pre-treatment of the cells with $1 \mu \mathrm{M} 1 \mathrm{DMe}$ for 20 minutes at $20^{\circ} \mathrm{C}$ did not induce any change in the distribution of MOP receptors along the sucrose gradient (figure 4A). Moreover, the distribution of inhibitory G protein subunits, which are coupled to the MOP receptor and are also enriched in lipid raft fractions, was unaffected by 1DMe (figure 4B). It is thus clear that the membrane compartmentation of MOP receptor that is affected by $1 \mathrm{DMe}$ in living cell is unrelated to the receptor confinement that is extrapolated from detergent-free isolation of buoyant membrane fractions. This implies that the basis for $1 \mathrm{DMe}$-sensitive MOP receptor confinement in living cells might not be the lipidic microcompartmentation of the membrane. Beside lipid rafts, MOP receptor confinement could be due to the cytoskeleton acting as a fence [28] or to other types of protein/protein interactions [29]. These 
interactions could be disrupted by $1 \mathrm{DMe}$-induced $\mathrm{MOP}-\mathrm{NPFF}_{2}$ oligomerization [7] leading to a change in lateral diffusion.

We have shown here a total lack of correlation, not only between MOP receptor confinement observed in living cells and in membrane fractions, but even between results obtained with two membrane fractionation methods. Our data emphasize that, in the case of the MOP receptor, care should be taken when extrapolating results obtained from membrane fractionation and cholesterol depletion to explain the organization of receptor signaling in living cells. This is another example of the methodological issues that arise when trying to probe the reality of lateral heterogeneity in biological membranes [30, 31]. There is an evident need for complementing biochemical isolation data with more direct and dynamic approaches in living cells such as FRAP, fluorescence correlation spectroscopy or single particle tracking $[32,33]$.

\section{Acknowledgements:}

This research was supported by the French Agence Nationale de la Recherche, "Neurosciences, Neurologie et Psychiatrie” Program, grant number ANR-06-NEURO-041-04.

\section{References:}

[1] P. Panula, A. A. Aarnisalo, and K. Wasowicz, Neuropeptide FF, a mammalian neuropeptide with multiple functions, Prog Neurobiol 48 (1996) 461-487.

[2] M. Roumy, and J. M. Zajac, Neuropeptide FF, pain and analgesia, Eur J Pharmacol 345 (1998) 1-11.

[3] S. Fukusumi, R. Fujii, and S. Hinuma, Recent advances in mammalian RFamide peptides: the discovery and functional analyses of PrRP, RFRPs and QRFP, Peptides 27 (2006) 1073-1086.

[4] J. M. Zajac, Neuropeptide FF: new molecular insights, Trends Pharmacol Sci 22 (2001) 63. 
[5] C. Mollereau, M. Roumy, and J. M. Zajac, Opioid-modulating peptides: mechanisms of action, Curr Top Med Chem 5 (2005) 341-355.

[6] C. Mollereau, H. Mazarguil, J. M. Zajac, and M. Roumy, Neuropeptide FF (NPFF) analogs functionally antagonize opioid activities in NPFF2 receptor-transfected SH-SY5Y neuroblastoma cells, Mol Pharmacol 67 (2005) 965-975.

[7] M. Roumy, C. Lorenzo, S. Mazeres, S. Bouchet, J. M. Zajac, and C. Mollereau, Physical association between neuropeptide FF and micro-opioid receptors as a possible molecular basis for anti-opioid activity, J Biol Chem 282 (2007) 8332-8342.

[8] P. A. Insel, B. P. Head, H. H. Patel, D. M. Roth, R. A. Bundey, and J. S. Swaney, Compartmentation of G-protein-coupled receptors and their signalling components in lipid rafts and caveolae, Biochem Soc Trans 33 (2005) 1131-1134.

[9] S. Maekawa, S. Iino, and S. Miyata, Molecular characterization of the detergent-insoluble cholesterol-rich membrane microdomain (raft) of the central nervous system, Biochim Biophys Acta 1610 (2003) 261-270.

[10] M. Bari, N. Battista, F. Fezza, A. Finazzi-Agro, and M. Maccarrone, Lipid rafts control signaling of type-1 cannabinoid receptors in neuronal cells. Implications for anandamide-induced apoptosis, J Biol Chem 280 (2005) 12212-12220.

[11] P. Savi, J. L. Zachayus, N. Delesque-Touchard, C. Labouret, C. Herve, M. F. Uzabiaga, J. M. Pereillo, J. M. Culouscou, F. Bono, P. Ferrara, and J. M. Herbert, The active metabolite of Clopidogrel disrupts P2Y12 receptor oligomers and partitions them out of lipid rafts, Proc Natl Acad Sci U S A 103 (2006) 11069-11074.

[12] A. Andre, G. Gaibelet, L. Le Guyader, M. Welby, A. Lopez, and C. Lebrun, Membrane partitioning of various delta-opioid receptor forms before and after agonist activations: The effect of cholesterol, Biochim Biophys Acta 1778 (2008) 1483-1492. 
[13] B. P. Head, H. H. Patel, D. M. Roth, N. C. Lai, I. R. Niesman, M. G. Farguhar, and P. A. Insel, Gprotein-coupled receptor signaling components localize in both sarcolemmal and intracellular caveolin3-associated microdomains in adult cardiac myocytes, J Biol Chem 280 (2005) 31036-31044.

[14] P. Huang, W. Xu, S. I. Yoon, C. Chen, P. L. Chong, and L. Y. Liu-Chen, Cholesterol reduction by methyl-beta-cyclodextrin attenuates the delta opioid receptor-mediated signaling in neuronal cells but enhances it in non-neuronal cells, Biochem Pharmacol 73 (2007) 534-549.

[15] P. Huang, W. Xu, S. I. Yoon, C. Chen, P. L. Chong, E. M. Unterwald, and L. Y. Liu-Chen, Agonist treatment did not affect association of mu opioid receptors with lipid rafts and cholesterol reduction had opposite effects on the receptor-mediated signaling in rat brain and CHO cells, Brain Res 1184 (2007) $46-56$.

[16] P. Huang, C. Chen, W. Xu, S. I. Yoon, E. M. Unterwald, J. E. Pintar, Y. Wang, P. L. Chong, and L. Y. Liu-Chen, Brain region-specific N-glycosylation and lipid rafts association of the rat mu opioid receptor, Biochem Biophys Res Commun 365 (2008) 82-88.

[17] H. H. Patel, B. P. Head, H. N. Petersen, I. R. Niesman, D. Huang, G. J. Gross, P. A. Insel, and D. M. Roth, Protection of adult cardiac myocites from ischemic cell death: role of caveolar microdomains and delta-opioid receptors, Am J Physiol Heart Circ Physiol 291 (2006) H344-350.

[18] W. Xu, S. I. Yoon, P. Huang, Y. Wang, C. Chen, P. L. Chong, and L. Y. Liu-Chen, Localization of the kappa opioid receptor in lipid rafts, J Pharmacol Exp Ther 317 (2006) 1295-1306.

[19] H. Zhao, H. H. Loh, and P. Y. Law, Adenylyl cyclase superactivation induced by long-term treatment with opioid agonist is dependent on receptor localized within lipid rafts and is independent of receptor internalization, Mol Pharmacol 69 (2006) 1421-1432.

[20] L. Mouledous, J. Neasta, S. Uttenweiler-Joseph, A. Stella, M. Matondo, M. Corbani, B. Monsarrat, and J. C. Meunier, Long-term morphine treatment enhances proteasome-dependent degradation of G beta in human neuroblastoma SH-SY5Y cells: correlation with onset of adenylate cyclase sensitization, Mol Pharmacol 68 (2005) 467-476. 
[21] K. S. Song, S. Li, T. Okamoto, L. A. Quilliam, M. Sargiacomo, and M. P. Lisanti, Co-purification and direct interaction of Ras with caveolin, an integral membrane protein of caveolae microdomains. Detergent-free purification of caveolae microdomains, J Biol Chem 271 (1996) 9690-9697.

[22] D. A. Brown, Lipid rafts, detergent-resistant membranes, and raft targeting signals, Physiology (Bethesda) 21 (2006) 430-439.

[23] B. Lagane, G. Gaibelet, E. Meilhoc, J. M. Masson, L. Cezanne, and A. Lopez, Role of sterols in modulating the human mu-opioid receptor function in Saccharomyces cerevisiae, J Biol Chem 275 (2000) 33197-33200.

[24] L. J. Pike, X. Han, and R. W. Gross, Epidermal growth factor receptors are localized to lipid rafts that contain a balance of inner and outer leaflet lipids: a shotgun lipidomics study, J Biol Chem 280 (2005) 26796-26804.

[25] K. Ohira, S. Maekawa, and M. Hayashi, Absence of TrkB and insulin receptor beta in the Triton insoluble low-density fraction (raft), Neuroreport 11 (2000) 1307-1311.

[26] G. P. Eckert, U. Igbavboa, W. E. Muller, and W. G. Wood, Lipid rafts of purified mouse brain synaptosomes prepared with or without detergent reveal different lipid and protein domains, Brain Res $962(2003) 144-150$.

[27] A. Sauliere, G. Gaibelet, C. Millot, S. Mazeres, A. Lopez, and L. Salome, Diffusion of the mu opioid receptor at the surface of human neuroblastoma SH-SY5Y cells is restricted to permeable domains, FEBS Lett 580 (2006) 5227-5231.

[28] K. Suzuki, K. Ritchie, E. Kajikawa, T. Fujiwara, and A. Kusumi, Rapid hop diffusion of a Gprotein-coupled receptor in the plasma membrane as revealed by single-molecule techniques, Biophys $\mathrm{J}$ 88 (2005) 3659-3680.

[29] F. Daumas, N. Destainville, C. Millot, A. Lopez, D. Dean, and L. Salome, Interprotein interactions are responsible for the confined diffusion of a G-protein-coupled receptor at the cell surface, Biochem Soc Trans 31 (2003) 1001-1005. 
[30] S. Mishra, and P. G. Joshi, Lipid raft heterogeneity: an enigma, J Neurochem 103 Suppl 1 (2007) $135-142$.

[31] D. Lichtenberg, F. M. Goni, and H. Heerklotz, Detergent-resistant membranes should not be identified with membrane rafts, Trends Biochem Sci 30 (2005) 430-436.

[32] A. Baker, A. Sauliere, F. Dumas, C. Millot, S. Mazeres, A. Lopez, and L. Salome, Functional membrane diffusion of G-protein coupled receptors, Eur Biophys J 36 (2007) 849-860.

[33] K. Jacobson, O. G. Mouritsen, and R. G. Anderson, Lipid rafts: at a crossroad between cell biology and physics, Nat Cell Biol 9 (2007) 7-14.

\section{Figure Legends:}

Figure 1: MOP-YFP receptor distribution is dependent upon the method used to prepare lipid raft fractions. Left panel, cells were solubilized in $0.2 \%$ Triton X-100. Right panel, cells were solubilized in $500 \mathrm{mM}$ sodium carbonate $\mathrm{pH} 11$. AP, alkaline phosphatase activity expressed as a percentage of the total activity along the gradient. Samples from each fraction were loaded on 10\% SDS-PAGE gels and immunoblotted using antibodies directed against flotillin or GFP to detect YFP-tagged MOP receptors. Data are representative of at least 3 independent experiments.

Figure 2: Methyl- $\beta$-cyclodextrin treatment alters MOP-YFP receptor distribution and signaling. A, Cells were treated with $\pm \mathrm{M} \beta \mathrm{CD} 5 \mathrm{mM}$ for $1 \mathrm{~h}$ at $37^{\circ} \mathrm{C}$ before detergent-free raft preparation. MOP-YFP receptors were detected using antibodies directed against GFP. B, DAMGO dose-response curves for the inhibition of forskolin-induced cAMP production. Control refers to forskolin $(5 \mu \mathrm{M})$ in the absence of DAMGO. Data are means \pm S.E.M. of five experiments performed in duplicates. 
Figure 3: $\mathrm{NPFF}_{2}$ receptors are predominantly distributed outside lipid rafts and their signaling is unaffected by cholesterol depletion. A, Cells were solubilized either in $0.2 \%$ Triton X-100 or in $500 \mathrm{mM}$ sodium carbonate $\mathrm{pH}$ 11. Samples from each fraction were loaded on 10\% SDS-PAGE gels and immunoblotted using antibodies directed against GFP to detect YFP-tagged $\mathrm{NPFF}_{2}$ receptors. Two bands at about 130 and $90 \mathrm{kDa}$ correspond to the receptor. Data are representative of at least 3 independent experiments. B, 1DMe dose-response curves for the inhibition of forskolin-induced cAMP production. Control refers to forskolin $(5 \mu \mathrm{M})$ in the absence of 1DMe. Data are means \pm S.E.M. of three experiments performed in duplicates.

Figure 4: 1DMe pre-treatment does not alter the distribution of MOP receptors and inhibitory $G$ proteins. Cells were pre-treated with $1 \mu \mathrm{M}$ of $1 \mathrm{DMe}$ for 20 minutes at $20^{\circ} \mathrm{C}$. Lipid rafts were prepared using the detergent-free method. A, the quantity of MOP receptors in each fraction is expressed as a percentage of the total amount of receptors along the gradient (as assessed by image analysis of immunoblots). $\mathrm{B}$, the quantity of $\mathrm{G} \alpha_{\mathrm{i} 3}$ and $\mathrm{G} \beta$ subunits detected on immunoblots in lipid raft fractions (4-5) is expressed as a percentage of control untreated cells. Flotillin was used for normalization. Data are expressed as means \pm S.E.M. of three independent experiments. 

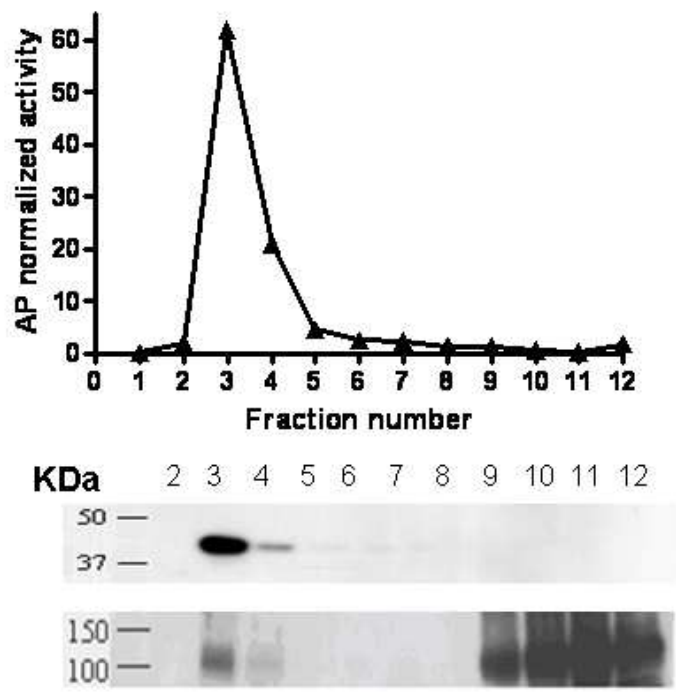

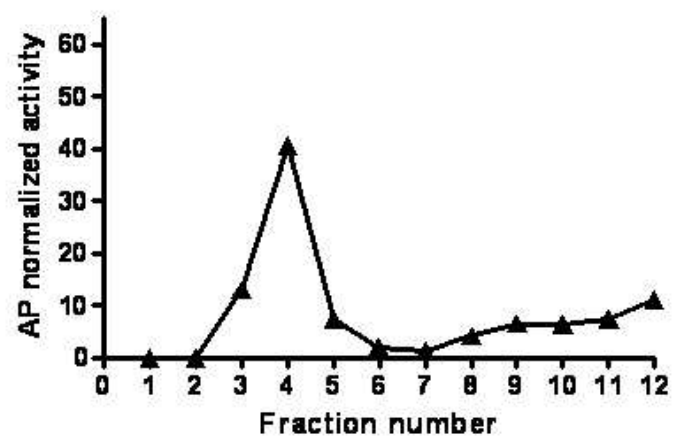

Flotillin

MOP-YFP

Figure 1 

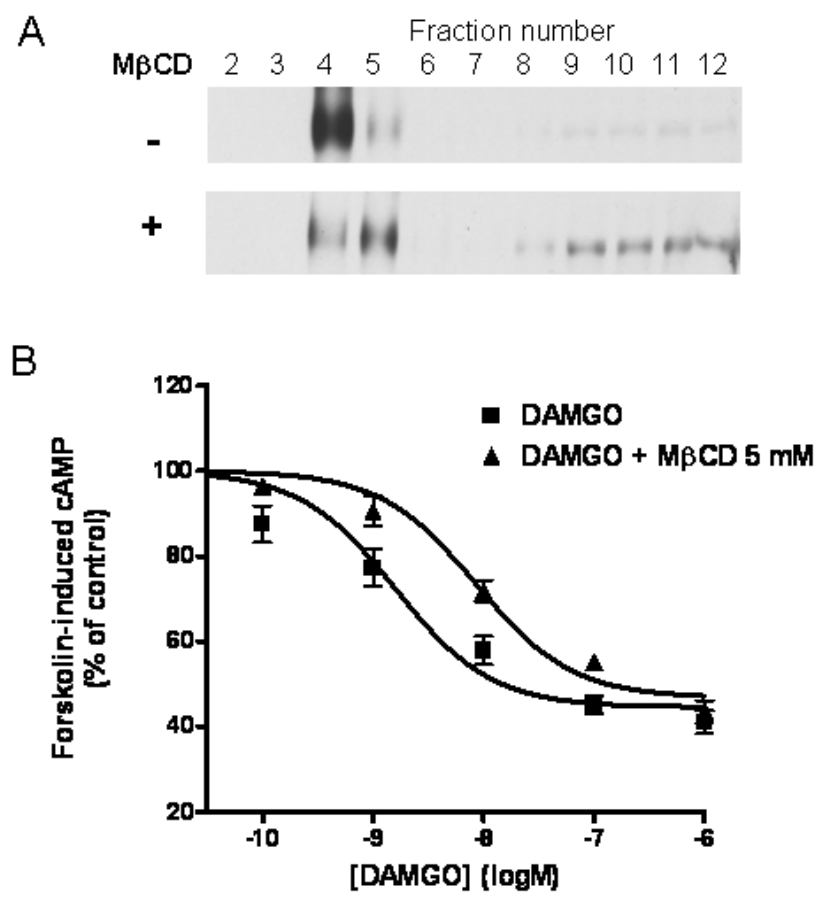

Figure 2 
A

$$
\begin{array}{lllllllllll}
2 & 3 & 4 & 5 & 6 & 7 & 8 & 9 & 10 & 11 & 12
\end{array}
$$

Triton X-100

\section{Detergent-free}

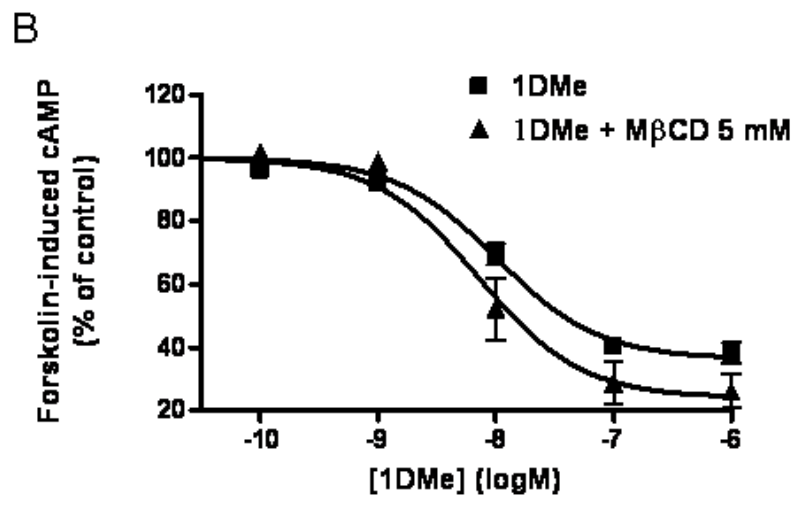

Figure 3 
A

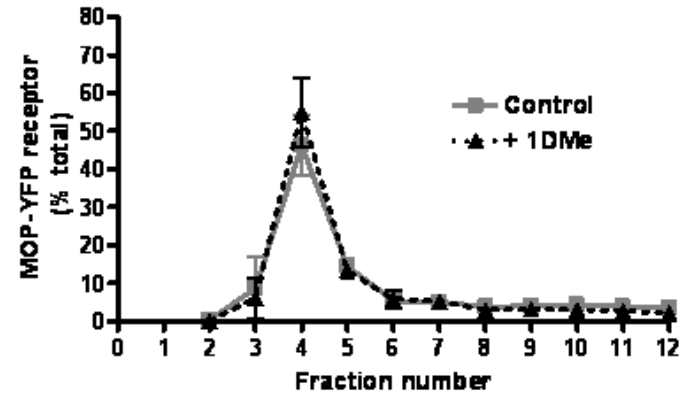

B

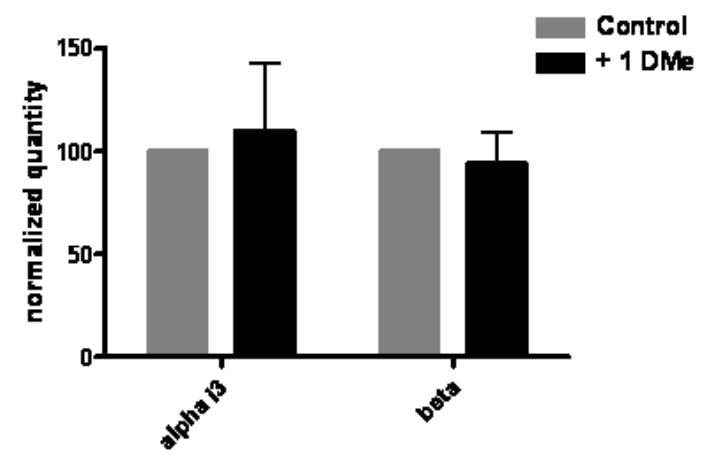

Figure 4 